\title{
Penatalaksanaan Acute Low-tone Sensorineural Hearing Loss
}

\author{
Jenny Tri Yuspita Sari ${ }^{1}$, Jacky Munilson ${ }^{2}$, Rossy Rosalinda ${ }^{2}$ \\ 1. RSUD Solok; 2. RSUP dr. M. Djamil, Padang
}

Korespondensi: Jenny Tri Yuspita Sari, email: jenny.yuspitasari@gmail.com

\begin{abstract}
Abstrak
Acute Low-tone Sensorineural Hearing Loss (ALHL) merupakan ketulian mendadak sensorineural pada nada rendah dengan penyebab yang tidak diketahui secara jelas (idiopatik) dan tidak disertai dengan keluhan vertigo. Tujuan: Melaporkan ALHL sebagai salah satu kegawatdaruratan di bagian telinga hidung tenggorok bedah kepala dan leher (THT-KL) yang memerlukan tindakan penanganan yang cepat. Diagnosis dini dan penatalaksanaan segera pada kasus ALHL dapat meningkatkan angka kesembuhan dan menurunkan risiko ketulian permanen pada pasien. Kasus: Dilaporkan seorang pasien perempuan 22 tahun dengan diagnosis Acute Low-tone Sensorineural Hearing Loss telinga kanan. Pasien datang dengan keluhan telinga berdengung, telinga terasa penuh, penurunan pendengaran tanpa disertai dengan pusing berputar. Pasien diberikan terapi kombinasi kortikosteroid dengan terapi tambahan lainnya dan menunjukkan perbaikan komplit dalam 2 minggu terapi. Simpulan: Pemberian terapi yang cepat dan tepat (terapi inisial) dapat memberikan perbaikan yang maksimal pada pasien dengan ALHL. Evaluasi terapi awal sangat berpengaruh terhadap prognosis jangka panjang pasien ALHL, terutama evaluasi pada satu bulan pertama.
\end{abstract}

Kata kunci: acute low-tone sensorineural hearing loss; idiopatik; vertigo; kortikosteroid; terapi inisial

\section{Abstract}

Acute Low-tone Sensorineural Hearing Loss (ALHL) is a sudden sensorineural hearing loss at low frequency with unknown cause without vertigo. Objectives: To report ALHL as one of the emergency cases in the otorhinolaryngology head and neck surgery (ORL-HNS) department. Early diagnosis and immediate management can improve the cure rate and reduce the risk of permanent hearing loss in patient. Case: A 22-year-old female patient reported with diagnosis Acute Low-tone Sensorineural Hearing Loss on the right ear. Patient complain with buzzing ear, fulness sensation on the right ear, decrease of hearing without spinning dizziness. Patient were given combination corticosteroid therapy with other adjuvant medication and showed complete improvement within 2 weeks of therapy. Conclusions: Provision of prompt and appropriate therapy can provide the maximum improvement in patients with ALHL. The initial therapeutic evaluation was highly influential on the long-term prognosis of ALHL patients, especially the evaluation in the first month.

Keywords: acute low-tone sensorineural hearing loss; idiopathic; vertigo; corticosteroid; initial therapy 


\section{PENDAHULUAN}

Acute Low-tone Sensorineural Hearing Loss (ALHL) merupakan tuli sensorineural pada frekuensi rendah yang terjadi tanpa keluhan pusing berputar dan melibatkan patofisiologi yang bervariasi. ALHL merupakan salah satu kegawatdaruratan di bagian THT-KL yang memerlukan penanganan segera. ${ }^{1-4} \mathrm{ALHL}$ sangat sering terjadi namun tidak banyak pencatatan yang dibuat karena sebagian besar ahli tidak menetapkan ALHL sebagai penyakit yang berbeda dari tuli mendadak atau Sudden Sensorineural Hearing Loss (SSNHL). ${ }^{5}$

Insiden ALHL dilaporkan 42,8-65,8 per 100.000 populasi di Jepang 5 dan $18 \%$ dari pasien yang didiagnosis SSNHL atau tuli mendadak ${ }^{4}$. Fushiki menyebutkan kejadian ALHL diperkirakan mencapai 40-60 per 100.000 orang berdasarkan survei regional. ${ }^{6}$ Berbeda dengan tuli mendadak atau SSNHL yang lebih banyak terjadi pada usia tua, ALHL lebih banyak terjadi pada pasien usia muda. Terdapat perbedaan antara laki-laki dan perempuan dan hampir sebagian besar kasus ALHL bersifat unilateral. $^{7}$ Sampai saat ini belum ada konsensus yang menetapkan terapi khusus

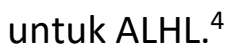

Kortikosteroid sistemik merupakan modalitas utama pada terapi ALHL. Pemberian kortikosteroid dapat diberikan terpisah atau dikombinasikan dengan diuretik. Selain itu terapi injeksi kortikosteroid intratimpani juga dikembangkan dalam beberapa waktu terakhir. ${ }^{7,8}$ Sebagaimana yang disebutkan oleh Jung, penelitian terhadap pasien ALHL menunjukkan 32-65\% pasien sembuh tanpa pengobatan. ${ }^{8}$ Anak-anak dan pasien berusia di atas 40 tahun memiliki prognosis yang jelek, sama halnya dengan tuli sensorineural pada frekuensi tinggi. Meskipun pasien dengan ALHL memiliki prognosis yang lebih baik bila dibandingkan dengan pasien tuli mendadak (SSNHL), 9-47\% pasien yang sembuh mengalami kekambuhan. Sebanyak $10 \%$ dari mereka berkembang menjadi penyakit Meniere. Oleh karena itu beberapa ahli menyatakan ALHL sebagai gejala awal dari penyakit Meniere dan sebagian lainnya menyatakan ALHL sebagai bagian dari hidrops endolimfe. ${ }^{7}$

Artikel ini bertujuan melaporkan ALHL sebagai salah satu kegawatdaruratan di bagian telinga hidung tenggorok bedah kepala dan leher (THT-KL) yang memerlukan tindakan penanganan yang cepat.

\section{LAPORAN KASUS}

Seorang pasien perempuan umur 22 tahun datang ke IGD RSUP Dr. M. Djamil pada tanggal 16 November 2017 dengan keluhan telinga kanan berdengung sejak 12 hari sebelum masuk rumah sakit. Pasien merasakan telinga berdengung hilang timbul. Penurunan pendengaran sejak 2 hari sebelumnya. Telinga terasa penuh hilang timbul sejak 1 minggu sebelumnya. Tidak ada nyeri, riwayat trauma dan riwayat keluar cairan dari kedua telinga. Pasien tidak mengeluhkan pusing 
berputar. Tidak ada riwayat demam, batuk dan pilek sebelumnya. Pasien tidak memiliki riwayat hipertensi dan diabetes melitus. Pasien seorang mahasiswa

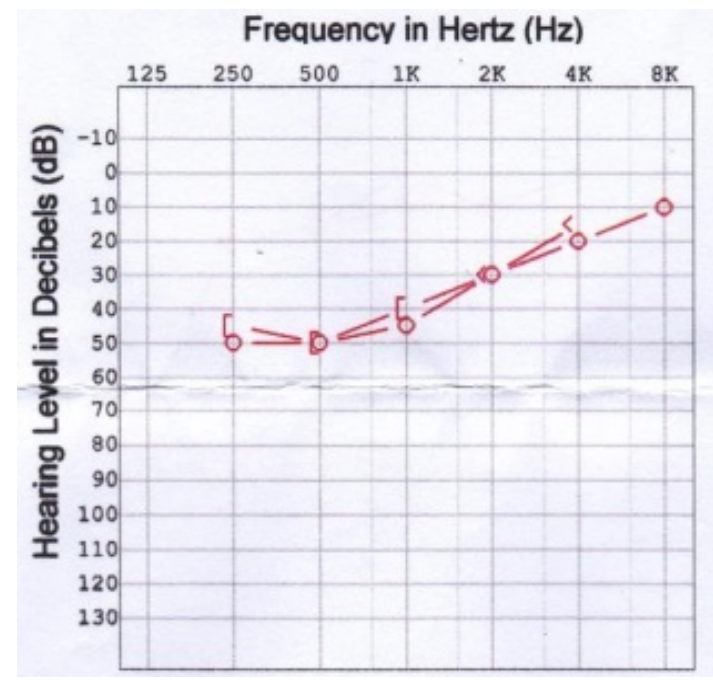

\section{Gambar 1. Audiogram awal}

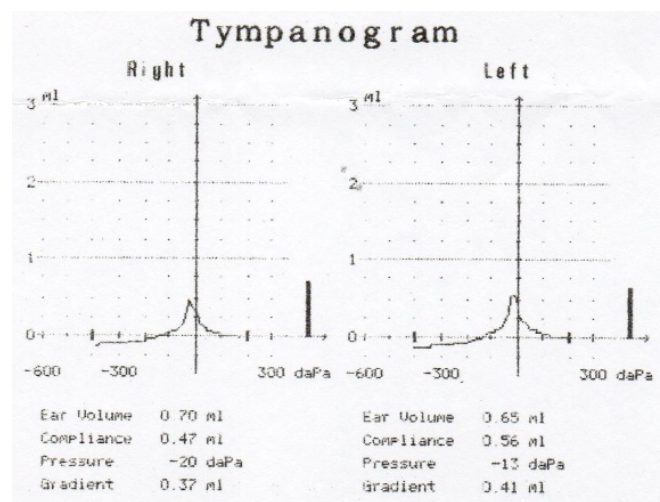

\section{Gambar 2. Timpanogram}

Pada pemeriksaan umum, didapatkan keadaan umum baik dengan tanda vital dalam batas normal. Pada pemeriksaan THT-KL didapatkan kedua liang telinga lapang, membran timpani utuh dan refleks cahaya ada. Pada pemeriksaan hidung dan tenggorok tidak ditemukan kelainan. Pemeriksaan penala lima frekuensi didapatkan kesan tuli sensorineural telinga kanan pada frekuensi $128,256,512$, dan $1024 \mathrm{~Hz}$. Hasil pemeriksaan audiometri menunjukkan kesan tuli sensorineural kedokteran gigi dengan kesibukan praktikum setiap hari dalam 1 bulan terakhir.

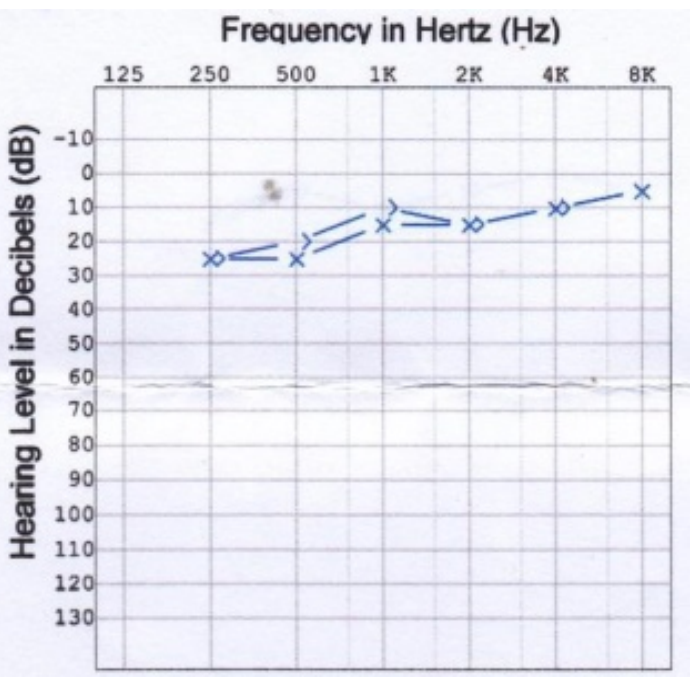

derajat ringan dengan ambang dengar $36,25 \mathrm{~dB}$ pada telinga kanan. Pada telinga kiri didapatkan hasil normal dengan ambang dengar 16,25 dB. Pemeriksaan timpanometri tipe A pada kedua telinga. Pemeriksaan keseimbangan dan koordinasi sederhana dapat dilakukan dengan baik. Pada tes Gaze tidak didapatkan nistagmus.

Pemeriksaan laboratorium darah didapatkan $\mathrm{Hb} \quad 12,8 \mathrm{~g} / \mathrm{dL}$, leukosit $6.700 / \mathrm{mm} 3$, trombosit $366.000 / \mathrm{mm} 3$, hematokrit 39, PT 10,3 detik, APTT 35,9 detik, INR 1, GDR $100 \mathrm{mg} / \mathrm{dL}$, total kolesterol $196 \mathrm{mg} / \mathrm{dL}$, HDL kolesterol 45 $\mathrm{mg} / \mathrm{dL}$, LDL kolesterol $132 \mathrm{mg} / \mathrm{dL}$, trigliserida $95 \mathrm{mg} / \mathrm{dL}$. Hasil laboratorium darah dalam batas normal. Pasien didiagnosis dengan Acute low-tone sensorineural hearing loss $A D$ dan dirawat di bagian THT-KL. Pasien ditatalaksana dengan istirahat total dan diberikan terapi 
oksigen 4L/menit selama 15 menit tiap 6 jam, drip pentoksifilin $300 \mathrm{mg}$ dalam RL $500 \mathrm{cc} 8 \mathrm{jam} /$ kolf, metilprednisolon 1x64 mg per oral dengan pengurangan dosis bertahap setiap tiga hari, injeksi

Frequency in Hertz $(\mathrm{Hz})$

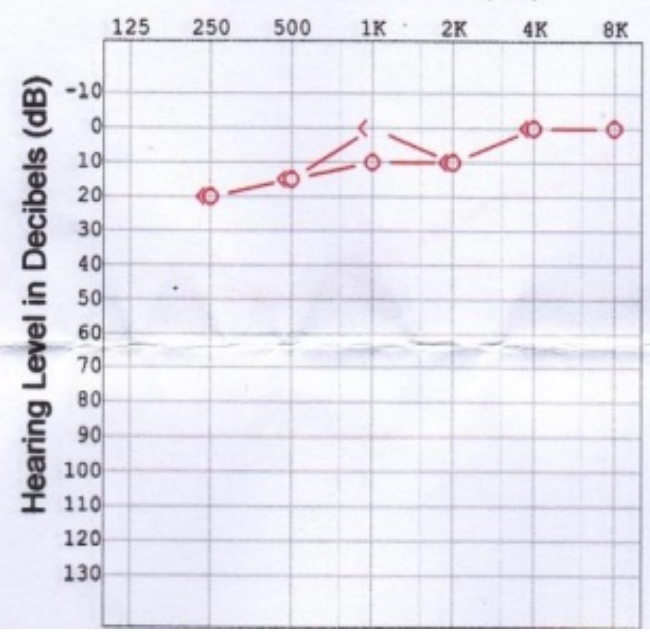

Gambar 3. Audiogram minggu pertama

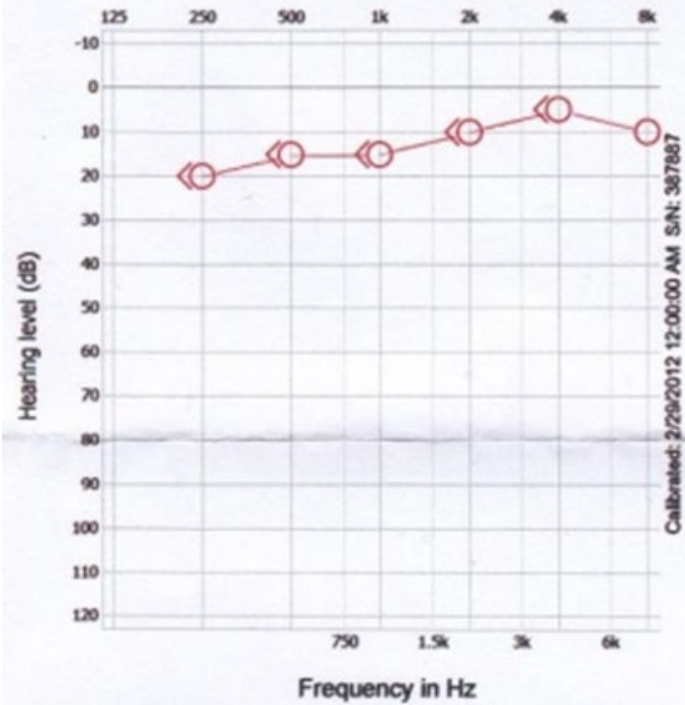

Gambar 4. Audiometri bulan pertama mekobalamin $3 \times 500 \mu \mathrm{g}$, injeksi vitamin C 2x100 mg dan injeksi neurotropik (vitamin B1 100mg, vitamin B6 100mg, vitamin B12 $5.000 \mathrm{mcg}) 1 \times 1$ ampul.
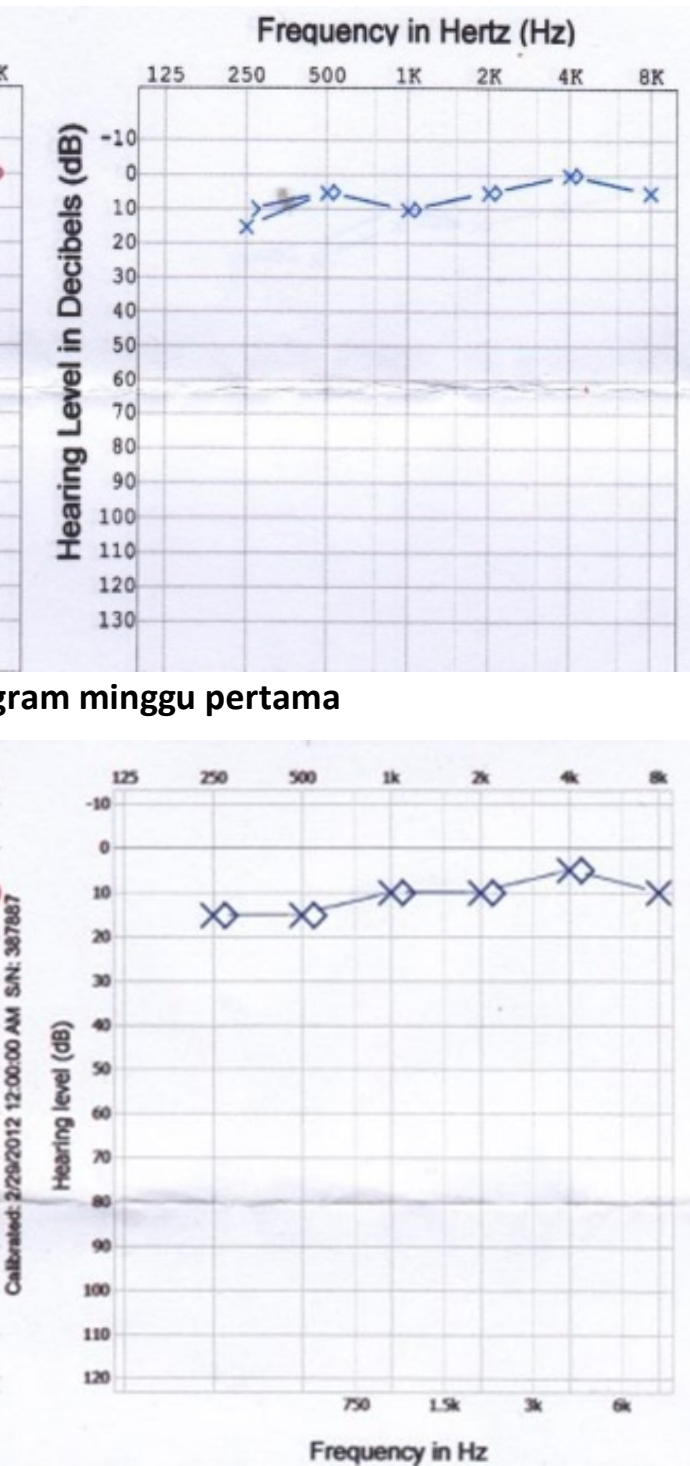

Hari keempat rawatan pada tanggal 19 November 2017, keluhan telinga berdengung mulai berkurang. Telinga terasa penuh dan pusing berputar tidak ada. Pemeriksaan kedua telinga dalam batas normal. Pemeriksaan penala lima frekuensi dengan kesan tuli sensorineural telinga kanan pada frekuensi rendah. Hari ketujuh rawatan keluhan telinga berdenging berkurang, penurunan pendengaran dan rasa penuh di telinga tidak ada. Pemeriksaan kedua telinga tidak ada kelainan. Pemeriksaan penala lima frekuensi dengan kesan normal pada 
kedua telinga. Pasien dilakukan audiometri ulang, didapatkan hasil telinga kanan normal dengan ambang dengar 8,75 dB dan telinga kiri normal dengan ambang dengar $5 \mathrm{~dB}$. Pasien diberikan tablet

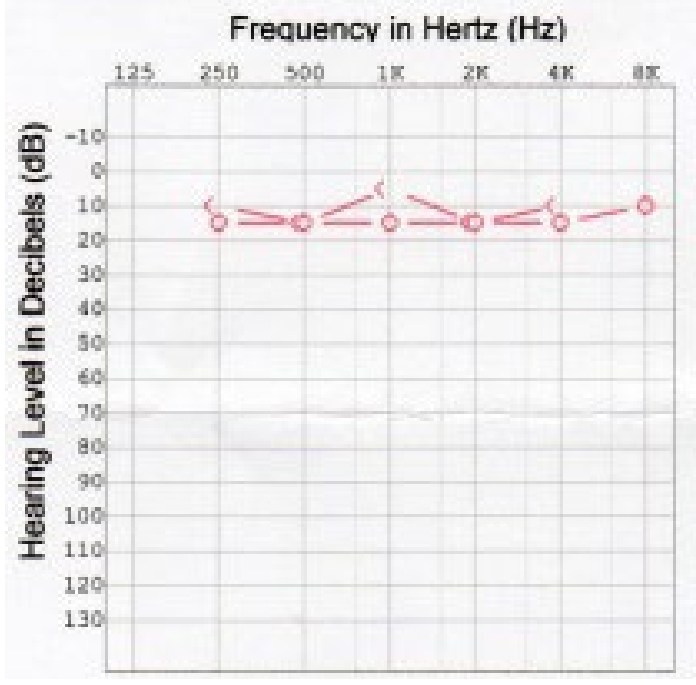

metilprednisolon,

pentoksifilin, mekobalamin, vitamin C, dan neurotropik tablet Pasien dianjurkan untuk kontrol ulang 1 minggu lagi.

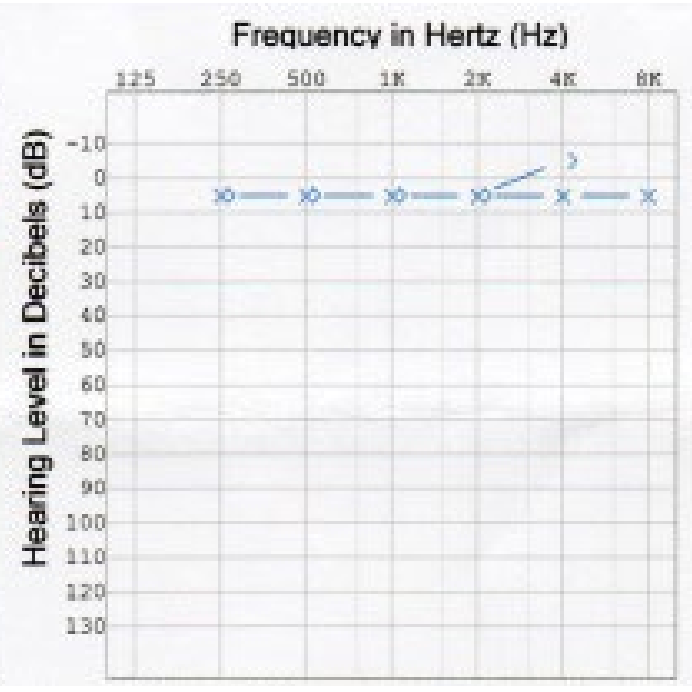

Gambar 5. Audiometri bulan kedua

Tabel 1. Pemeriksaan penala

\begin{tabular}{|c|c|c|c|c|}
\hline Penala $(\mathrm{Hz})$ & Telinga & Rinne & Weber & Scwabbach \\
\hline \multirow{2}{*}{128} & Kanan & + & \multirow{2}{*}{ Lateralisasi kiri } & memendek \\
\hline & Kiri & - & & $=$ pemeriksa \\
\hline \multirow{2}{*}{256} & Kanan & + & \multirow{2}{*}{ Lateralisasi kiri } & memendek \\
\hline & Kiri & - & & $=$ pemeriksa \\
\hline \multirow{2}{*}{512} & Kanan & + & \multirow{2}{*}{ Lateralisasi kiri } & memendek \\
\hline & Kiri & - & & $=$ pemeriksa \\
\hline \multirow{2}{*}{1024} & Kanan & + & \multirow{2}{*}{ Lateralisasi kiri } & memendek \\
\hline & Kiri & - & & $=$ pemeriksa \\
\hline \multirow{2}{*}{2048} & Kanan & + & \multirow{2}{*}{ Lateralisasi (-) } & $=$ pemeriksa \\
\hline & Kiri & - & & $=$ pemeriksa \\
\hline
\end{tabular}

Pasien kontrol ulang pada tanggal 18 Desember 2017. Keluhan telinga berdengung dirasakan kembali 3 hari sebelumnya namun hilang dengan sendirinya. Penurunan pendengaran tidak ada. Evaluasi ulang audiometri didapatkan hasil normal pada kedua telinga dengan ambang dengar 11,25 dB pada telinga kanan $10 \mathrm{~dB}$ pada telinga kiri. Kontrol selanjutnya pada tanggal 15 Januari 2017 dan keluhan tidak ada. Pemeriksaan audiometri didapatkan telinga kanan normal dengan ambang dengar $15 \mathrm{~dB}$ dan telinga kiri normal dengan ambang dengar $5 \mathrm{~dB}$. Pasien dianjurkan kontrol ulang 3 bulan lagi.

\section{PEMBAHASAN}


Telah dilaporkan kasus dengan diagnosis Acute Lowtone Hearing Loss (ALHL) telinga kanan pada perempuan usia 22 tahun. Yoshida dalam penelitiannya menemukan kejadian ALHL yang banyak pada wanita muda, sesuai dengan beberapa penelitian sebelumnya. ${ }^{7}$ Sementara Choi menyatakan bahwa penderita terbanyak adalah wanita, rata-rata pada usia empat puluhan. ${ }^{8} \mathrm{ALHL}$ banyak ditemukan dalam praktik seharihari. Pasien biasanya datang dengan keluhan tinitus nada rendah, autofoni, rasa penuh di telinga yang disertai dengan penurunan pendengaran tanpa pusing berputar. ALHL dapat didiagnosis dengan audiometri nada murni. ${ }^{8,9,10}$ Dahulu ALHL sering disamakan dengan Idiopathic Sudden Sensorineural Hearing Loss (ISSNHL), namun sekarang dapat ditegakkan sebagai diagnosis tersendiri. Pasien AHLH tidak mengalami penurunan pendengaran yang berat dan kadangkadang gejalanya tidak jelas. ${ }^{4,9}$ Pada kasus di atas, pasien datang dengan keluhan telinga berdengung, telinga terasa penuh pada sisi yang sakit dan penurunan pendengaran. Pasien tidak merasa pusing berputar. Pada audiometri pasien ini tidak mengalami penurunan pendengaran pada frekuensi tinggi (4.000 dan $8.000 \mathrm{~Hz}$ ).

Abe sebagaimana dikutip oleh Sato melaporkan penelitian terhadap 39 pasien penderita ALHL dengan penyebab yang tidak jelas. ${ }^{4}$ Semua pasien mengalami penyembuhan komplit tanpa kekambuhan dan fluktuasi gejala. Abe menyatakan ALHL sebagai diagnosis khusus yang berbeda dengan tuli mendadak, dimana ketulian terbatas hanya pada frekuensi rendah dan prognosis lebih baik. Sedangkan Yamasoba sebagaimana dikutip oleh Hong menyatakan bahwa rekurensi dan fluktuasi sering terjadi pada ALHL dan pada beberapa pasien berkembang menjadi penyakit Meniere. ${ }^{1}$ Sebagian besar etiologi pada ALHL diduga idiopatik sama halnya dengan tuli mendadak. Mekanisme utama yang terlibat dalam patofisiologi utama adalah hidrops endolimfatik. Fuse sebagaimana dikutip oleh Morita menyatakan bahwa etiologi ALHL melibatkan respon autoimun pada saccus endolimfatik yang memicu terjadinya hidrops endolimfatik. ${ }^{9}$ Fuse sendiri dalam penelitiannya menemukan adanya ketidakseimbangan rasio Th1/Th2 yang biasanya berhubungan dengan kejadian dan progresivitas penyakit-penyakit tertentu seperti karsinoma dan penyakit autoimun. ${ }^{11}$ Hasil pemeriksaan darah pasien dalam batas normal. Tidak ada faktor risiko lain yang ditemukan pada pasien. Diduga penyebab tuli sensorineural pada pasien adalah idiopatik. Karena keterbatasan alat dan sarana penunjang, tidak dapat dilakukan pemeriksaan tes gliserin dan elektrokokleografi (EChoG).

Pasien dirawat di bangsal THT-KL selama 1 minggu. Sesuai dengan panduan praktik klinis di bagian THT-KL RSUP M. Djamil, pasien mendapat terapi oksigen tiap 6 jam selama 15 menit, injeksi metilprednisolon, pentoksifilin, vitamin C, mekobalamin dan neurotropik. Morita menyatakan kortikosteroid sebagai terapi utama pada ALHL. ${ }^{9}$ Akan tetapi jenis, dosis dan cara 
pemberiannya tidak ada ketetapan khusus.

Fuse menyatakan bahwa terapi utama pada ALHL adalah kortikosteroid dan diuretik. ${ }^{11}$ Menurut Chang pemberian kortikosteroid bisa tunggal atau kombinasi dengan. ${ }^{12}$ Chang menyimpulkan bahwa pemberian kortikosteroid dapat menjadi pilihan untuk terapi jangka pendek pada pasien ALHL. ${ }^{12}$

Menurut Oishi metilprednisolon diberikan dengan dosis $30-60 \mathrm{mg} /$ hari sebagai dosis awal. $^{5}$ Sedangkan Choi16 memberikan metilprednisolon $40 \mathrm{mg}$ pada hari 1-3, 30 mg pada hari 4-6, 20 mg pada 7-9 dan 10 mg pada hari 10-12. Pasien pada kasus ini diberikan metilprednisolon 1x64 mg dengan penurunan dosis bertahap tiap 3 hari selama 12 hari. Choi juga menyatakan terapi dapat dikombinasikan dengan vitamin B12 dan adenosin trifosfat yang berfungsi untuk meningkatkan suplai darah di koklea dan proteksi koklea terhadap stres oksidatif. Selain itu diuretik atau vasodilator juga dapat diberikan. Menurut Fuse steroid jangka panjang memiliki efek samping, sehingga perlu diberikan kombinasi terapi yang dapat mengembalikan ketidakseimbangan perbandingan Th1/Th2 untuk mencegah rekurensi. ${ }^{11}$ Salah satunya adalah pentoksifilin, yang dapat menjadi pilihan untuk kombinasi terapi sekaligus sebagai vasodilator. Pasien pada kasus ini mendapatkan pentoksifilin injeksi $3 \times 500$ mg yang di-drip dalam RL 500 cc.

Morita mengembangkan injeksi kortikosteroid sebagai salvage terapi pada ALHL yang tidak respon dengan terapi inisial. ${ }^{9}$ Choi memilih deksametason sebagai terapi injeksi intratimpani dan tetap memberikan metilprednisolon oral sebagai kombinasi terapi. ${ }^{8}$ Menurut Jung perbaikan lebih banyak pada pasien yang diberikan steroid oral daripada steroid intratimpani. ${ }^{13}$

Pasien mendapatkan pengobatan setelah keluhan dirasakan selama 12 hari. Dalam evaluasinya pasien mengalami perbaikan dan peningkatan ambang dengar. Menurut Chang jarak waktu antara munculnya gejala dengan waktu pemberian terapi awal sangat mempengaruhi perbaikan ambang dengar dalam 1 bulan pertama. Saat pasien mendapatkan terapa inisial yang terlambat, sedikit sekali perbaikan yang dicapai dalam 1 bulan. Beberapa penelitian sebelumnya juga menyebutkan persentase perbaikan pendengaran meningkat saat pasien mendapatkan terapi inisial 1 minggu setelah onset gejala. ${ }^{12}$

Pasien dilakukan audiometri 1 minggu setelah terapi awal dan menunjukkan peningkatan ambang dengar pada frekuensi rendah. Begitu juga dengan audiometri 1 bulan berikutnya. Keluhan telinga berdengung dan penurunan pendengaran juga berkurang setelah terapi inisial. Sesuai dengan kriteria hasil pengobatan yang diusulkan oleh Study Group for Acute Profound Deafness Research Committee of The Ministry of Health, Labor and Welfare of Japan, dalam penilaian 1 bulan pertama pasien ini mengalami perbaikan komplit karena 
ambang dengar kembali dalam batas normal. ${ }^{9}$

Terdapat berbagai pendapat sehubungan dengan prognosis pasien dengan ALHL. Menurut Fuse prognosis pasien ALHL tidak dipengaruhi oleh usia, derajat penurunan pendengaran awal maupun waktu mendapatkan terapi. ${ }^{14}$ Sedangkan Choi menyatakan faktor yang mempengaruhi respon terapi adalah usia dan interval waktu onset dengan pengobatan. ${ }^{8}$ Choi mendapatkan prognosis usia muda lebih baik begitu juga dengan durasi yang cepat dalam mendapatkan pengobatan inisial. ${ }^{8}$ Sedikit berbeda dengan pendapat Jung yang menemukan faktor prognosis ALHL adalah durasi waktu onset dengan terapi awal, beratnya tinitus dan derajat penurunan pendengaran awal sebelum mendapat terapi. ${ }^{13}$

Dalam pengobatan pasien ALHL salah satu perhatian utama adalah prognosis jangka panjang. Oishi menjelaskan bahwa penurunan pendengaran sisa setelah terapi awal atau fluktuasi pendengaran selama 1 tahun pertama setelah onset pertama berhubungan dengan prognosis selama 10 tahun. ${ }^{5}$ Sebanyak $42 \%$ dari pasien yang mengalami penyembuhan komplit pada tahun pertama tidak mengalami rekurensi dalam 10 tahun. Pendapat ini juga diperkuat oleh Roh yang menyatakan derajat pendengaran setelah terapi awal mempengaruhi derajat pendengaran jangka panjang. ${ }^{10}$ Fushiki menyebutkan angka rekurensi ALHL mencapai hampir $80 \%$ jika didapatkan keterlibatan vestibular dan hidrops endolimfatik pada ECochG. ${ }^{6}$

\section{SIMPULAN}

ALHL dapat dipisahkan sebagai satu kesatuan yang berbeda dengan respon yang lebih baik terhadap pengobatan serta memiliki prognosis yang baik. Pengobatan ALHL harus dilakukan segera untuk meningkatkan efektivitas terapi. Pemberian kortikosteroid sebagai terapi utama dapat dikombinasikan dengan obatobat lainnya sebagai terapi tambahan. Evaluasi terapi harus selalu dilakukan, baik jangka pendek maupun jangka panjang karena prognosis jangka panjang yang baik dipengaruhi oleh respon terapi awal yang dinilai dalam satu bulan pertama.

\section{DAFTAR PUSTAKA}

1. Hong SK, Nam SW, Lee H, Koo JW, Kim DH, Kim DR, et al. Clinical Observation on Acute LowFrequency Hearing Loss Without Vertigo: The Role of Cochlear Hydrops Analysis Masking Procedure as Initial Prognostic Parameter. Ear Hear. 2013; 34:229-35. doi: 10.1097/AUD.0b013e31826a1cae.

2. Noguchi $Y$, Nishida H, Kawashima $Y$, Tokano H, Kitamura K. Comparison of acute low-tone sensorineural hearing loss versus meniere's disease by electrocochleography. Ann Otol Rhinol Laryngol. 2004; 113(3 Pt 1):1-5. doi: 10.1177/000348940411300304. 
3. Shimono $M$, Teranishi $M$, Yoshida $T$, Kato $M$, Sano $R$, Otake $H$, et al. Endolymphatic Hydrops Revealed by Magnetic Resonance Imaging in Patients With Acute Low-Tone Sensorineural Hearing Loss. Otol Neurotol. 2013; 34:1241-6. doi: 10.1097/MAO.0b013e3182990e81.

4. Sato H, Kuwashima S, Nishio S, Kitoh R, Fukuda S, Hara A, et al. Epidemiological survey of acute low-tone sensorineural hearing loss. Acta Otolaryngol. 2017; 137(sup565):S34-S37. doi: 10.1080/00016489.2017.1297538.

5. Oishi N, Inoue $\mathrm{Y}$, Saito H, Kanzaki S, Kohno N, Ogawa K. Long term prognosis of low frequency hearing loss and predictive factors for the 10 years outcome. Otolaryngol Neck Surg. 2010; 142(4):565-9. doi: 10.1016/j.otohns.2009.12.006.

6. Fushiki $H$, Junicho $M$, Aso $S$, Watanabe $Y$. Recurrence Rate of Idiopathic Sudden Low-Tone Sensorineural Hearing Loss Without Vertigo: A Long-Term Follow-Up Study. Otol Neurotol. 2009; 30(6):295-8.

7. Yoshida T, Sone M, Kitoh R, Nishio SY, Ogawa K, Kanzaki S, et al. Idiopathic sudden sensorineural hearing loss and acute low-tone sensorineural hearing loss : a comparison of the results of a nationwide epidemiological survey in Japan. Acta Otolaryngol. 2017; 137(sup565):S38-S43. doi: 10.1080/00016489.2017.1297539.

8. Choi HG, Park KH, Seo JH, Kim DK, Yeo SW, Park SN. Clinical and Audiologic Characteristics of Acute Low-Tone Sensorineural Hearing Loss: Therapeutic Response and Prognosis. Korean J Audiol. 2011; 15(1):8-13.

9. Morita S, Suzuki M, lizuka K. A Comparison of the Short-Term Outcome in Patients with Acute LowTone Sensorineural Hearing Loss. ORL J Otorhinolaryngol Relat Spec. 2010; 72(6):295-9. doi: $10.1159 / 000314695$.

10. Roh KJ, Lee EJ, Park AY, Choi B II, Son EJ. Long-Term Outcomes of Acute Low-Tone Hearing Loss. J Audiol Otol. 2015; 19(2):74-8. doi: 10.7874/jao.2015.19.2.74.

11. Fuse $T$, Hayashi $T$, Oota $N$, Fukase $S$, Asano $S$, Kato $T$, Aoyagi $M$. Immunological responses in acute low-tone sensorineural hearing loss and Ménière's disease. Acta Otolaryngol. 2003; 123(1):26-31.

12. Chang J, Yum G, Im H, Jung JY, Rah YC, Choi J. Short-Term Outcomes of Acute Low-Tone Sensorineural Hearing Loss According to Treatment Modality. J Audiol Otol. 2016; 20(1):47-52. doi: 10.7874/jao.2016.20.1.47.

13. Jung AR, Kim MG, Kim SS, Kim SH, Yeo SG. Clinical characteristics and prognosis of low frequency sensorineural hearing loss without vertigo. Acta Otolaryngol. 2016; 136(2):159-63. doi: 10.3109/00016489.2015.1094824.

14. Fuse T, Aoyagi M, Funakubo T, Sakakibara A, Yoshida S. Short-Term Outcome and Prognosis of Acute Low-Tone Sensorineural Hearing Loss by Administration of Steroid. ORL J Otorhinolaryngol Relat Spec. 2002; 64(1):6-10. doi: 10.1159/000049079. 